\title{
Un turismo de cemento para los argentinos. El consumo de departamentos en Mar del Plata (1950-1970)
}

\author{
Tourism of Concrete for Argentine People. The Use of \\ Apartments in Mar del Plata (1950-1970) \\ Víctor Pegoraro \\ Universidad Nacional de Mar del Plata
}

DOI: https://doi.org/10.25032/crh.v6i10.8

Recibido: $31 / 3 / 2020$

Aprobado: 18/5/2020

Resumen. El artículo analiza el fenómeno de consumo de bienes inmobiliarios para fines turísticos en la ciudad de Mar del Plata entre 1950 y 1970. La compra de departamentos en propiedad horizontal fue una conducta económica y cultural específica de las clases medias argentinas en un contexto determinado. Espontáneamente, las llamadas «unidades de temporada» se transformaron en objetos deseados y necesarios para mantener y ostentar un estilo de vida. La posibilidad de poseer una segunda vivienda frente al mar resolvía el problema de alojamiento para asiduos visitantes y familias enteras en el balneario de moda. En este sentido, se examinan las causas que incentivaron la inversión individual, el perfil de los compradores, las características de los inmuebles junto con las estrategias publicitarias de venta y las representaciones subyacentes.

Palabras clave: Mar del Plata, turismo, departamentos, clases medias

Summary: The article analyzes the phenomenon of demand for real state for tourist purposes, in Mar del Plata city between 1950 and 1970. The purchase of apartments was a specific economic and cultural behavior of the Argentine middle classes in a given context. Spontaneously, the so-called "seasonal units" became desired and required objects to hold and display a lifestyle. The chance of owning a second home facing the sea solved the issue of lodging for regular visitors and whole families in the trendy beach resort. In this context, the reasons that encouraged individual investment, the 
profile of buyers and the properties' features, are examined together with the advertising sale strategies and the underlying representations.

Keywords: Mar del Plata, tourism, apartments, middle classes

\section{Introducción}

La costa atlántica argentina tuvo un rol singular en la oferta nacional de destinos turísticos. A lo largo del siglo $\mathrm{xx}$, la paulatina democratización de acceso a estos espacios de ocio fue abriendo el abanico de posibilidades de los argentinos. Particularmente, el veraneo en Mar del Plata se convirtió en el fenómeno de mayor magnitud marcando la impronta para el desarrollo de balnearios vecinos. Múltiples sectores sociales se sintieron interpelados a concurrir a la playa, vale el ejemplo paradigmático de la llegada de los obreros a partir del peronismo. ${ }^{1}$

Aunque contaba con antecedentes en la década del treinta para el sector comercial, desde el año 1945 las vacaciones pagas se convirtieron en un derecho social. ${ }^{2}$ No obstante, las formas de materializarlas estuvieron atravesadas por niveles de ingreso diferenciados que repercutieron, claro está, en la elección final del destino, la contratación del alojamiento y la naturaleza del viaje. También el horizonte de expectativas y las perspectivas culturales de cada grupo incidieron en el modo de apropiación del ocio.

Mar del Plata entró en la cultura de masas tempranamente y, sobre todo, en la mente del consumidor medio y metropolitano de la ciudad de Buenos Aires (y zona de influencia). Principalmente, a él se dirigían los estímulos sensoriales de la publicidad gráfica (mar, aire fresco, naturaleza, calor), el gusto, la moda y aquellos valores asociados a las vacaciones (descanso, tiempo libre, relax) que liberaban de los dramas propios de las grandes urbes. En las décadas centrales del siglo las clases medias del país fueron las más interpeladas por los promotores del balneario.

\footnotetext{
1 Ver: Elisa Pastoriza y Juan Carlos Torre, Mar del Plata, un sueño de los argentinos, Buenos Aires, Edhasa, 2019. Elisa Pastoriza, La conquista de las vacaciones. Breve historia del turismo en la Argentina, Buenos Aires, Edhasa, 2011; Mónica Bartolucci (ed.), Mar del Plata. Imágenes urbanas, vida cotidiana y sociedad, Mar del Plata, UNMDP, 2002.

${ }^{2}$ En el año 1933 se sancionó la Ley n. ${ }^{\circ}{ }^{11723}$, a través de la cual se introdujeron algunas medidas de protección para los trabajadores como las vacaciones pagas para los empleados de comercio. En la década siguiente Juan Domingo Perón, entonces Secretario de Trabajo y Previsión, generalizó ese derecho a los trabajadores de todos los sectores mediante el Decreto n. ${ }^{\circ}$ 1740/45.
} 
Poseer una segunda vivienda en la costa no constituía una novedad, pero por años había sido prerrogativa de las clases sociales más acomodadas del país. Gracias a la puesta en práctica de la Ley de Propiedad Horizontal (1948), se abrió la posibilidad de adquirir un inmueble, de uso temporario y de dimensiones más reducidas, a un precio asequible para fines de descanso y veraneo. La medida facilitaba aquella oportunidad bajo un régimen de división de la propiedad que permitió, por un lado, la amortización de los costos de construcción y, por otro, la extensión del derecho a una porción más grande de ciudadanos.

Entre 1948 y 1970 en Mar del Plata se levantaron cientos de edificios en altura para aprovechar las condiciones del mercado basadas en una demanda eufórica (Pegoraro 2018). Los nuevos departamentos se transformaron en bienes de consumo que modelaron aspiraciones de época que solo podía alcanzar una franja social que estuviera en condiciones materiales de hacerlo. Prontamente, se transformaron en objetos deseados y necesarios para mantener y ostentar un determinado estilo de vida. Además, solucionaban el problema de alojamiento de cada temporada para visitantes asiduos y familias enteras.

La compra de departamentos en la costa atlántica en esas décadas (denominados «unidades de temporada») se perfiló como un rasgo económico y cultural estrictamente constitutivo de las clases medias argentinas. $Y$ este modelo de ocio tuvo un rol importante a la hora de marcar ciertas pautas de consumo privilegiadas y conquistar aspiraciones de larga data (Pastoriza 2002). Dicha demanda desató la época de explosión inmobiliaria y de mayor crecimiento edilicio de la ciudad con récords de construcción (Pegoraro 2017).

El objetivo del artículo es analizar este fenómeno de consumo económico y cultural de un bien en particular, con sus propias características, para fines turísticos en la ciudad de Mar del Plata y zona. Más allá de la satisfacción de una necesidad anual, la del alojamiento por determinada cantidad de días, los departamentos cumplieron un rol fundamental en la práctica de consumo como constructor de experiencias y de expectativas de distinción social. En nuestro país el estudio del consumo en clave histórica ha comenzado a despuntar, sin embargo, existe una relativa dispersión dentro del campo (Pérez 2015; Rocchi 1998; Lluch 2015). 
Aquí intentamos poner en diálogo diferentes perspectivas tocando el trasfondo turístico (veraneo), los consumidores (clases medias) y la historia económica (empresas y construcción). Dada su complejidad, examinaremos las causas que incentivaron la inversión individual del público en departamentos; el perfil de los compradores (proveniencia geográfica y social, nivel económico); las características de los inmuebles, sus comodidades y los usos; las estrategias publicitarias y las representaciones subyacentes. En este plano, las publicidades y los folletos de venta que circulaban por inmobiliarias, diarios, revistas y otros medios de difusión de todo el país produjeron poderosas imágenes que resultaron ser exitosas al provocar la compra inusitada y eufórica por parte de una franja social que demandaba estos bienes.

Las fuentes utilizadas privilegian la relación de la oferta con la demanda. En consecuencia, hemos rastreado cientos de publicidades de venta de edificios y una serie de listas de compradores. Los archivos privados de inmobiliarias y de empresas constructoras junto a las colecciones personales de determinados arquitectos locales han sido centrales. Asimismo, la prensa periódica y los folletos son una fuente de primer orden para analizar el mercado inmobiliario de la época ya que manifiestan las formas de comercialización utilizadas, los actores participantes, los tiempos de construcción requeridos, las diversas imágenes de la ciudad y las estrategias de captación del cliente a lo largo del tiempo.

\section{La posibilidad de poseer un departamento «frente al mar»}

\section{La inversión inmobiliaria de las clases medias}

En Buenos Aires se decía: voy a Mar del Plata a comprar un departamento y la gente venía y hacía cola frente a las oficinas hasta regresar con un boleto de compra-venta o una escritura en la mano. En realidad, se compraba cualquier cosa, era la fiebre de la inversión inmobiliaria (La Capital [Mar del Plata], mar. 13, 1981, p. 25).

Desde el siglo XIX la narrativa social de los argentinos se ha configurado en torno a la idea de un país de clase media. Según Ezequiel Adamovsky (2015), esta identidad que reúne elementos heterogéneos entre sí se tornó más visible en la década de 1930 y se terminó de galvanizar con el peronismo. Siguiendo el argumento, aunque no es una cosa directamente observable, se hace referencia a los grupos que se ubican en el estrato medio de la pirámide social. El trasfondo del razonamiento obedece sobre todo 
a cuestiones políticas dejando a un lado los aspectos económicos de esa autorrepresentación.

Por otro lado, Rubén George Oliven (2014), investigador brasilero y especialista en antropología urbana, afirma que el término clase media denota una aspiración que engloba una narrativa de distinción frente a otros grupos sociales. En este sentido, las prácticas de consumo resultan una dimensión esencial para mantener cierto status y un sentido de pertenencia. La posibilidad de adquirir ciertos bienes a los que otros sectores sociales no acceden por diversas causas (capacidad económica, gustos, satisfacción de necesidades, utilidad, subjetividad) puede ser analizado históricamente como consecuencia de procesos sociales determinados.

Particularmente, el uso de departamentos para vivienda ha sido estudiado por Rosa Aboy como elemento identitario de amplios sectores de la clase media argentina entre 1930 y 1960. El acceso a la propiedad de estas tipologías arquitectónicas marcó un cierto nivel de vida y determinadas culturas de habitar en ese período. Las comodidades, la amplitud de los ambientes y los barrios donde se emplazaron forjaron también fuertes imágenes simbólicas. De este modo, la casa propia en altura consolidó el ascenso social de las nuevas y tradicionales clases medias generando una fuerte autorrepresentación. 3

Entre las décadas del cincuenta y del setenta las condiciones del país maximizaron las posibilidades de inversión inmobiliaria de grandes capas de la clase media.4 La política de vivienda del peronismo (1946-1955), en torno a la Ley de Propiedad Horizontal de 1948, favoreció el acceso a los departamentos a sectores con capacidad de ahorro. Además, el gobierno incentivó la toma de créditos hipotecarios a bajos intereses para comprar este tipo de bienes. En principio, ello generó la trasformación de las tradicionales unidades que componían las «casas de renta» (como se conocían a los edificios de departamentos en el período anterior) al nuevo régimen y, por otro lado, la construcción nueva en varias ciudades. En el segundo lustro de los

3 Rosa Aboy, «Departamentos para las clases medias...» (2014); «Mafalda en casa...» (2011); «Ciudad, espacio...» (2010).

4 Sobre el caso de Buenos Aires: Anahí Ballent, «Casa colectiva, monobloque, propiedad horizontal...» (2014); para Rosario: Norma Lanciotti, Abraham Lavih, Florencia Brizuela y Marco Kofman, «Notas sobre el mercado inmobiliario...» (2017). 
cincuenta el financiamiento público disminuyó, pero la demanda privada siguió creciendo.

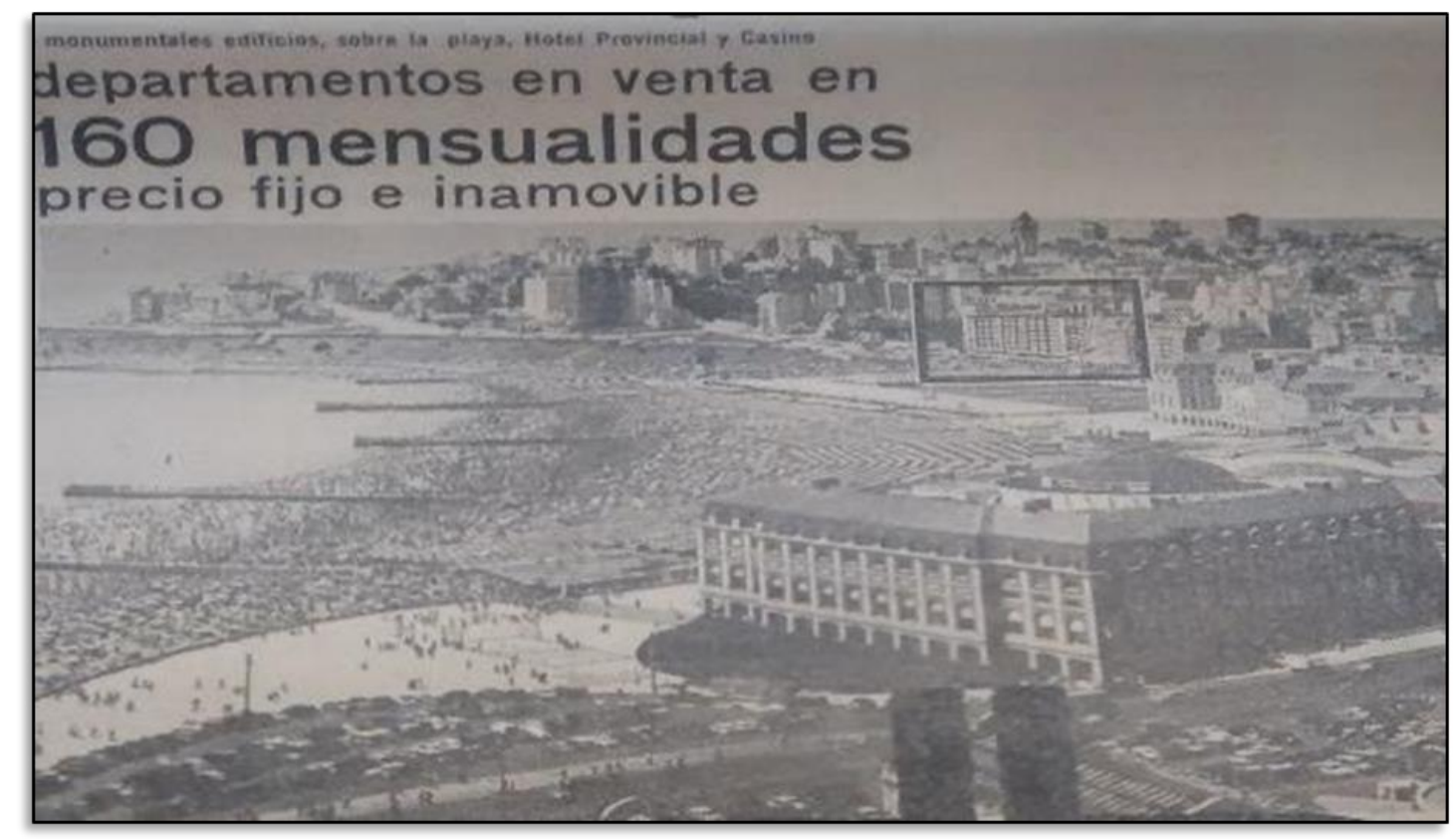

La Nación [Buenos Aires], dic. 6, 1961

Según Pablo Gerchunoff y Lucas Llach (1998), entre 1963 y 1973 la inflación arrojó un promedio del 29,2 \%, una de las más altas del mundo en ese momento. Sin embargo, en este decenio la Argentina experimentó una «primavera económica» que se tradujo en una ampliación del consumo a nuevos sectores de la población y en una consolidación del mercadointernismo. Ello se dio en una coyuntura de relativa distensión de las cuentas externas y de las consecuencias de los llamados «ciclos de stop and go», lo que permitió un crecimiento y un fuerte dinamismo. Este fue el período conocido como de «boom de la construcción» en todo el país donde, por ejemplo, el consumo anual de cemento pasó de 3.269.524 toneladas en 1965 a 5.394.178 toneladas en 1972.

En este contexto la atracción por la compra de departamentos en la costa atlántica para fines turísticos cundió en el horizonte de expectativas de los sectores medios del país. Mar del Plata se había convertido en la capital del turismo nacional donde arribaban miles de visitantes. 5 Establecida como una estación de baños de aguas templadas, las familias más importantes del país habían construido sus propias

5 En 1949 arribaron más de novecientos mil turistas, mientras que en 1969 superó la cantidad de dos millones de personas de personas. Ver: Elisa Pastoriza, La conquista de las vacaciones..... 
residencias de uso temporario a lo largo del litoral marítimo. Hasta la década del treinta solo la élite y la clase media alta porteña había podido lograr esta aspiración. Las villas de veraneo de estilo pintoresquista con sus amplios parques fueron su expresión arquitectónica. En el decenio siguiente los chalets de baja altura y de menores dimensiones se extendieron como el formato más usual para los sectores prósperos.

Dadas las nuevas posibilidades, favorecidas por la puesta en práctica de la Ley de Propiedad Horizontal, el anhelo de ser propietario de una vivienda de veraneo, aunque de dimensiones más reducidas, tuvo un carácter performativo. Poder veranear en Mar del Plata significaba para los crecientes grupos sociales medios en ascenso todo un símbolo: el disfrute de las vacaciones en familia, otrora restringido y el acceso al Casino más importante del país. La demanda espontánea fue tan grande que, paradójicamente, una gran porción de los futuros compradores declaraba que alquilaba la casa o el departamento donde residía en su ciudad de origen. Ello quiere decir que no en todos los casos se trató de una segunda vivienda, sino más bien de la primera.

Más allá de las conquistas simbólicas, en buena parte se trató de una conducta económica específica en un contexto particular. Como explica el economista Eduardo Corso (2014a), el impacto del deterioro de los activos de reserva socialmente establecidos desde décadas atrás en la Argentina como las cédulas hipotecarias (principal instrumento de ahorro de largo plazo en moneda local hasta el momento) y los títulos públicos (de bajo retorno), sumado a la presión inflacionaria y a la desestimación de los plazos fijos o la tenencia de moneda extranjera, hizo que la inversión en inmuebles comenzara a tomar forma como una opción no financiera de reserva de valor y de protección de los ahorros. El mercado se abrió primero en Mar del Plata y ahí se destinó una gran porción del ahorro nacional: en palabras del autor, nació así un shadow banking de la sociedad argentina (Corso 2014b). Los nuevos planes de financiación permitieron canalizar el ahorro y distribuir el capital necesario entre parcialidades «por el costo del veraneo». En la década del sesenta las facilidades de pago llegaron a las 160 cuotas a un «precio fijo e inamovible» (a bajo interés), dada la confianza en el sistema. 
Para resumir el argumento, tres fueron los factores claves e interrelacionados para desatar la inversión generalizada en este tipo de bienes. En principio, desde el punto de vista práctico la sanción y la reglamentación de la Ley de Propiedad Horizontal posibilitó la adquisición masiva de inmuebles por unidades independientes de un valor más reducido ya que permitió, por un lado, la integración de su costo total con el aporte de varios interesados y, por otro, saldar el total a través de un cómodo sistema de cuotas; en segundo lugar, en momentos en que otras alternativas de reserva de valor se encontraban desdibujadas, el público comenzó a demandar bienes fijos con el fin de proteger sus ahorros de modo que la inversión en ladrillos se transformó en una vía segura de reserva de valor. El tercer componente es de índole local, así como nacional. El avance de nuevos sectores medios, dispuestos a reclamar ciertos consumos que ahora se encontraban a su alcance, se convirtió en una práctica social a imitar: conquistar un espacio y un privilegio que habían monopolizado las clases altas por años.

\section{Las inmobiliarias y las representaciones sociales}

Hacia el 15 o 17 de agosto comenzaba el peregrinaje de las familias que querían un departamento en Mar del Plata y las señoras querían todo listo antes del $1^{\circ}$ de enero (Santiago Cocetta -histórico martillero público tasador-, entrevista personal, febrero de 2017).

Entre 1950 y 1970 Mar del Plata se consolidó definitivamente como mercancía y destino de las principales inversiones inmobiliarias fuera de la Capital Federal. Frente a otros tipos de alojamiento tradicional como hoteles y chalets, el departamento pasó ser objeto de deseo y figura inseparable de las nuevas formas de vida. Hacia 1960 el rubro inmobiliario local alcanzó un desarrollo exponencial y un apogeo sintomático de las oportunidades que venía ofreciendo el mercado, consolidándose así firmas dedicadas con exclusividad a la venta de edificios en propiedad horizontal y a los alquileres temporarios. Para mediados de la década, la ciudad ya contaba con un total de 109 inmobiliarias afirmadas como actores claves para cubrir la gran consulta y demanda de unidades durante todo el año. ${ }^{6}$

Desde temprano los promotores inmobiliarios se encargaron de crear representaciones sociales que calaron fuertemente en amplios sectores de la clase

\footnotetext{
${ }^{6}$ La Razón [Buenos Aires], nov. 22, 1965, p. 11.
} 
media. Comprar y poseer un «departamento con vista al mar» era sinónimo de distinción y de prestigio de forma de consolidar una posición frente a los demás. A partir de los años cincuenta las estrategias publicitarias se centraron en la circulación masiva de oferta de ventas en las páginas de los diarios tradicionales del país ( $L a$ Nación y La Prensa) y de las revistas de tirada nacional más distinguidas que circulaban entre estos estratos (El Hogar, Mundo Argentino, La Revista de Mar del Plata).
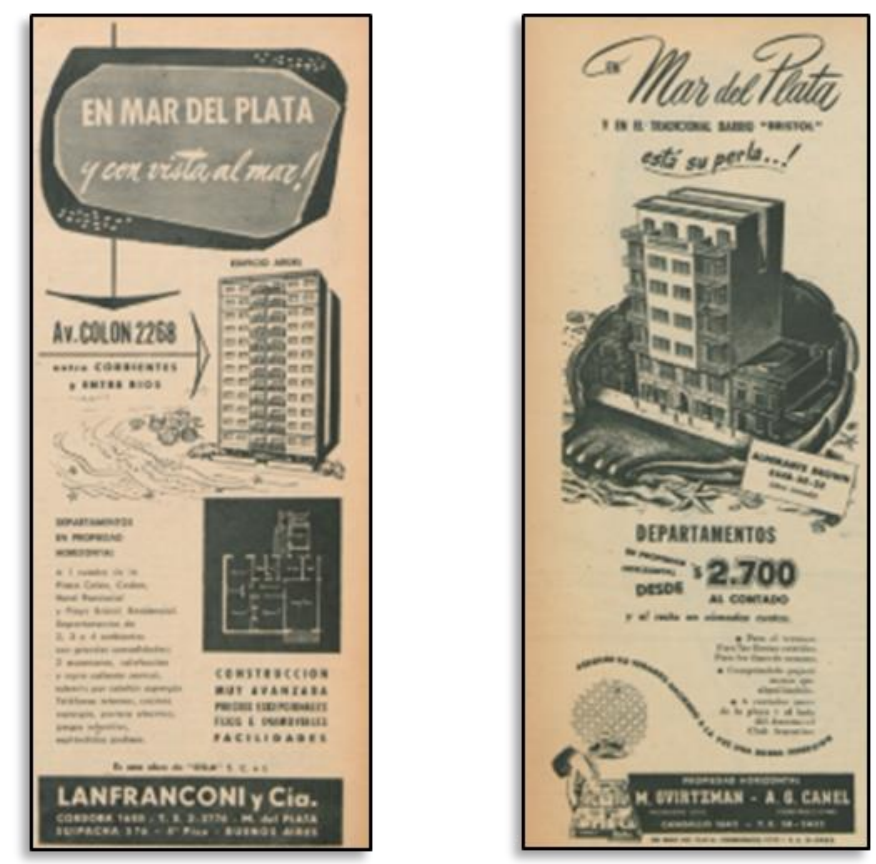

El Hogar, oct. 5, 1951, p. 36

El Hogar, feb. 22, 1952, p. 93

Bajo los estándares de la publicidad moderna (Rocchi 2017), la gráfica utilizada buscó superar el conocido aviso clasificado habitual por donde circulaba la propiedad inmueble. Así, las ilustraciones atractivas comenzaron a aparecer entre las páginas de contenidos varios como notas sociales, crónicas y misceláneas incentivando a comprar un bien distinto. Las estrategias para captar al lector se encargaron de crear una necesidad asociando indefectiblemente el disfrute del mar y de la playa con un departamento de cemento en altura. Paulatinamente, este tipo de imágenes inundó también otros medios de difusión algo más populares de modo de llegar a un vasto público. Sin embargo, el tenor y el lenguaje utilizado privilegiaron la misma lógica durante todo el período.

Tal fue el éxito de estas campañas que ya en el decenio siguiente era el púbico mismo el que buscaba directamente a las empresas constructoras y contactaba a las 
inmobiliarias. Así lo manifestaba el representante técnico de la firma más grande de la ciudad:

Era tal el mercado que había que [las empresas constructoras] no necesitaban publicitar. Lo primero que hacía la gente cuando venía de Buenos Aires era asegurarse de comprar un departamento. Ese era uno de los fundamentos para venir en el invierno. Si vos vendes un edificio en una semana ipara qué vas a hacer publicidad! La publicidad se la hacían ellos mismos, ellos mismos solos, ya en Buenos Aires todo el mundo conocía a las empresas locales. 7

Los departamentos fueron un bien de consumo dirigidos a los miles de visitantes que llegaban cada año. Sin embargo, no todos estuvieron en condiciones de compra ni contaban con la capacidad de ahorro necesaria. En los diferentes segmentos del mercado la oferta era el océano, el sol, la playa y el casino, brindando además elementos inexistentes en su lugar de origen como el agua de mar.

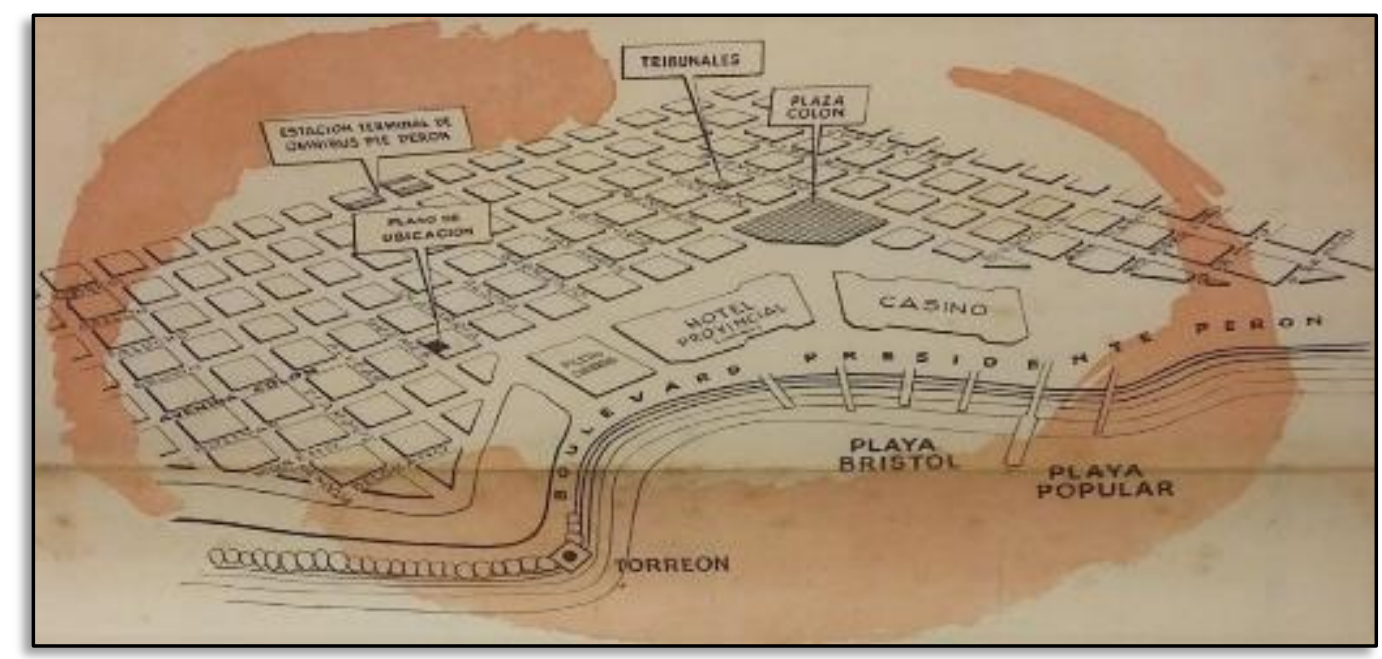

Referencias urbanas en la publicidad de la época (Fuente: Archivo Arq. Raúl Camusso, Colegio de Arquitectos de la Pcia. de Buenos Aires, Distrito IX)

Los puntos de referencia para el público fueron la Playa Bristol, la Playa Grande, la Playa Chica, el Hotel Provincial, el Casino Central, la Plaza Colón y la Estación de Ómnibus. En resumen, puntos de la ciudad que eran familiares para los asiduos veraneantes o los conocedores de los atractivos urbanos. Así los folletos rezaban: «a pasos de...», «cerca de...», «a cuadras de...». El progreso social de las clases medias en

\footnotetext{
7 Ing. Enrique Petersen (ex representante técnico de Nicolás Dazeo SA), entrevista, 2008. Archivo de la Imagen y la Palabra, CeHis.
} 
ascenso podía ser ahora materializado y visibilizado, en estos términos los vendedores conseguían llegar al consumidor.

Por ejemplo, una de las inmobiliarias más importantes de Buenos Aires, con asiento en la costa atlántica y más de cincuenta edificios construidos-vendidos, solía promocionar sus unidades con el siguiente slogan: «Por su prestigio, Ud. Merece vivir en Mar del Plata» $\mathrm{y}$ «Llegue al plano que Ud. merece por su ubicación social integrando el grupo que «puede» vivir en la Av. Colón. Un departamento digno de su prestigio». Maral Inmobiliaria atendía a una demanda de clase media alta, según invocaban sus leyendas, sus promotores y las comodidades ofrecidas por sobre el estándar en cada folleto. ${ }^{8}$ Claramente, el vivir no se correspondía con una necesidad habitacional sino con la mejor manera de disfrutar de un veraneo de excelencia.

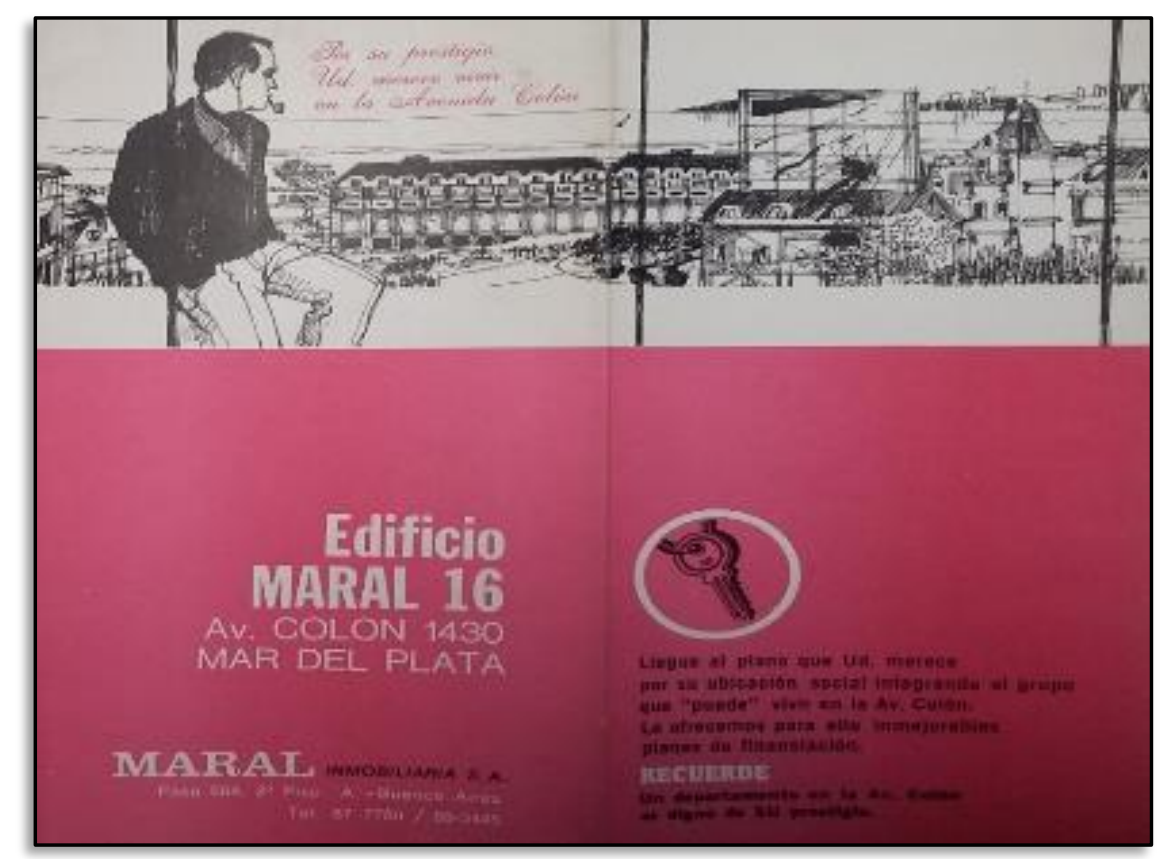

Publicidad de Maral Inmobiliaria, década del sesenta (Fuente: Archivo Arq. Raúl Camusso, Colegio de Arquitectos de la Pcia. de Buenos Aires, Distrito IX)

Otro caso paradigmático fue el de la inmobiliaria más resonante del medio local. En la década del sesenta Nannini-Barrera se convirtió en la oficina con más ventas de departamentos trabajando en exclusividad con las empresas constructoras. Su slogan

${ }^{8}$ Clarín [Buenos Aires], mar. 13, 1987, pp. 5-6. 
característico fue una marca registrada reproducida cada semana en la prensa: «El que no compra ni vende, no asciende». La imagen es elocuente al mostrar una posible pareja de clientes con reminiscencias de «clase media que ha experimentado una movilidad social ascendente: la vestimenta, el trabajo del hombre, el rol de la mujer y la actitud de ambos, son elementos que nos indican estas representaciones. El mejor modo de demostrarlo, según la publicidad, era comprar un departamento en Mar del Plata para solucionar el problema de las vacaciones. ${ }^{9}$

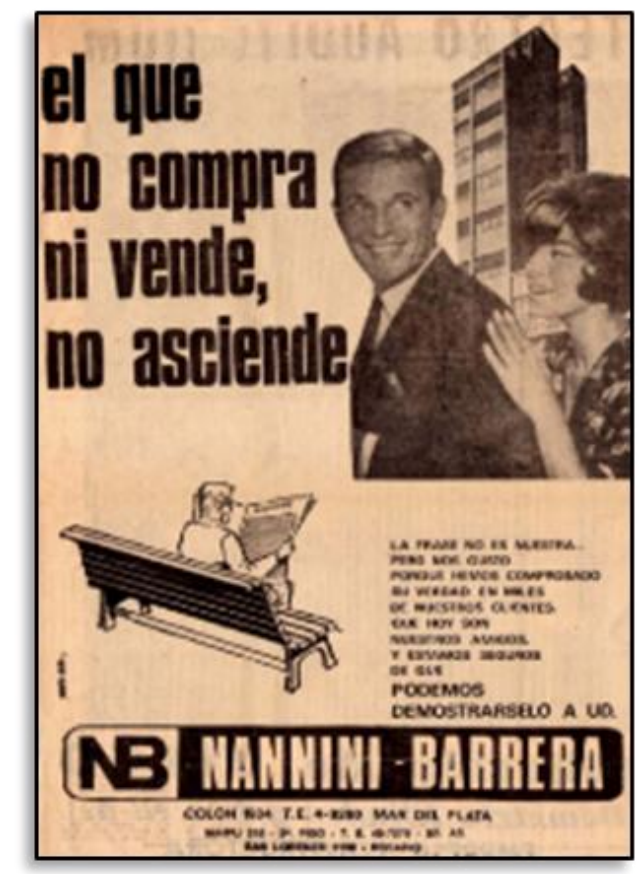

Publicidad de la inmobiliaria Nannini-Barrera. El trabajo [Mar del Plata], dic., 7, 1969

Por otro lado, los folletos desplegables mezclaban el lenguaje técnico de cada obra con apelaciones al interés del comprador y la ubicación donde se emplazarían los edificios: «la mejor ubicación», «en el barrio más aristocrático del balneario», «privilegio para pocos», «lujo y confort solo para usted», «veranee como un rey en Mar del Plata», «la playa a su alcance», «frente al mar», «señorío y categoría». Estas frases fueron muy exitosas al provocar la compra de cientos de unidades antes de ser construidas, generando una «euforia inmobiliaria» por no quedar afuera. A partir de este conjunto analizado, podemos entrever que las pretensiones de los usuarios eran claramente inferiores (con respecto a los departamentos para habitar de forma

9 Nannini-Barrera contaba con un stand anual y permanente en la Exposición Internacional de la Sociedad Rural en Palermo donde se promocionaban los edificios y las empresas de Mar del Plata. El Trabajo [Mar del Plata], jul. 10, 1968, p. 15. 
permanente en su lugar de origen) en favor de estar cerca del mar o con vistas a él.
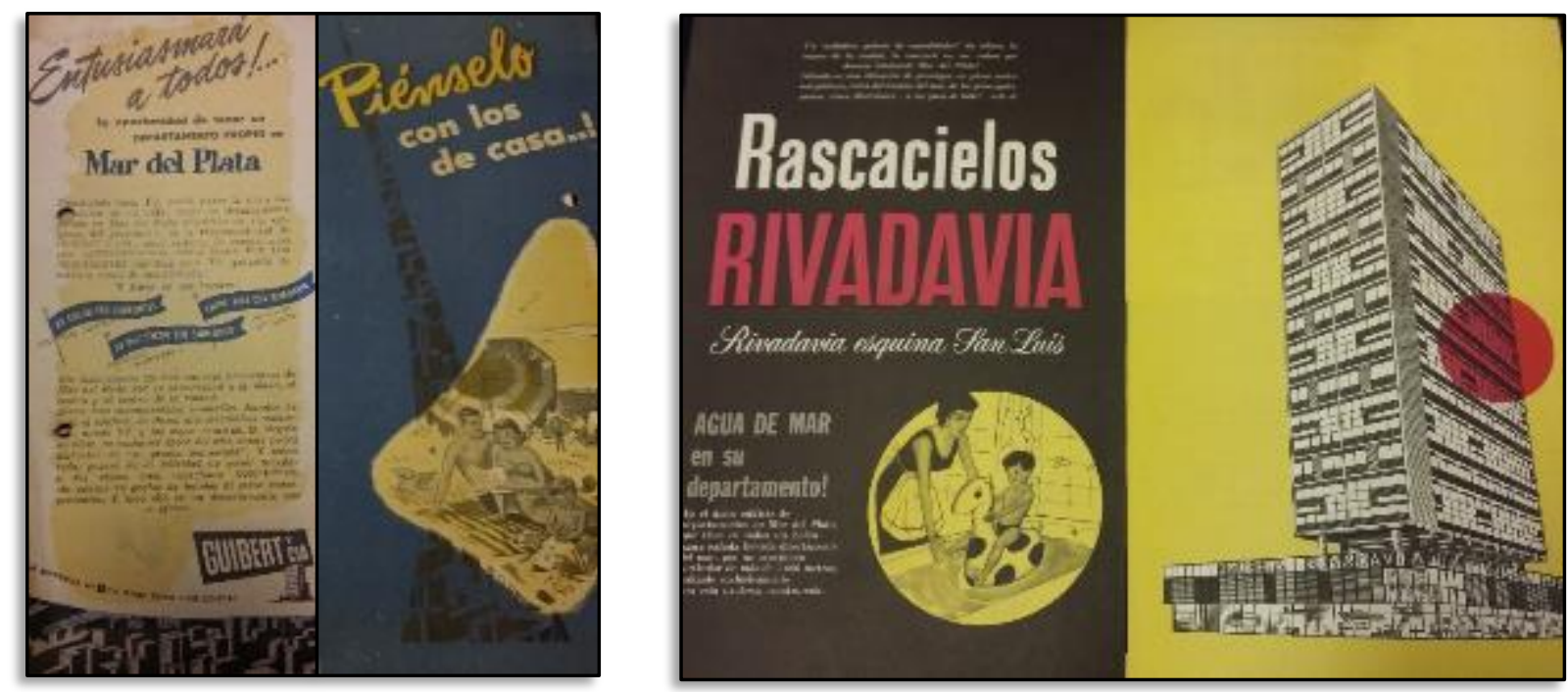

Folletos desplegables de edificios en propiedad horizontal (décadas del cincuenta y del sesenta).

(Fuente: Archivo Arq. Raúl Camusso, Colegio de Arquitectos de la Pcia. de Buenos Aires, Distrito IX)

\section{Las marcas comerciales en edificios}

Los nombres comerciales con las cuales eran conocidos los edificios fueron otro aliciente para lograr la venta de unidades. Las firmas de Buenos Aires desarrollaron sus propias marcas que vendían con gran éxito en todo el país: los edificios Maral (a la que ya hicimos alusión), Dormar, Jachal, Luchetti, Meir, entre otros, fueron parte de una oferta definida de inmuebles con gran repercusión de venta. Estos lograron, en algunos casos, una identificación en sus fachadas, en los halls de entrada y en las ubicaciones marcando la pauta. Este el caso de los Maral que, tras realizar una veintena bajo los patrones clásicos de construcción para turismo, ofrecieron de allí en más un conjunto con características especiales y una calidad superior a la media. Por ende, los últimos proyectos de la década del setenta estuvieron destinados a aquellos consumidores que pagaban un monto adicional, apuntando a una demanda de clase media alta. ${ }^{10}$

A partir de la década de 1960 las empresas constructoras locales de naturaleza familiar hicieron lo propio. Ello se tradujo en la creación de una seguidilla de edificios con un mismo nombre de fantasía que podía superar holgadamente la veintena. Así, cada empresa ideó su sello productivo de forma de conservar y mostrar una identidad individual, diferenciando sus productos dentro del mercado y por el cual era

${ }^{10}$ Alberto Shalom (fundador y propietario de Edificadora Maral), entrevista personal, agosto de 2016. 
reconocida dentro y fuera del medio. De este modo, la firma esgrimía una historia, una manera de trabajar, un modo de tratar con el cliente y un producto único en su serie que la diferenciaba de sus competidores. Asimismo, cada inmobiliaria sabía con qué tipo de constructora lidiaba y qué «mercancía» ofrecía a su clientela, desarrollando diferentes estrategias de comercialización.

En general, la costumbre fue bautizar a los edificios construidos con nombres de fantasía atractivos para el público. Así, sobresalen alusiones a: lugares o elementos del extranjero (Broadway, Bristol, Embassy, Lancaster, Las Vegas, Mont Blanc, Manacor, Montecarlo, San Francisco, Eiffel, Acapulco, California); Mar del Plata como calles o sitios del balneario (Playa Grande, Punta, Cabo Corrientes, Casino); nombre o apellido del dueño y sus familiares (padre, madre, hijos), o bien la ciudad de origen, apodo o la personalidad de su autor; sumatoria de la primera sílaba de los nombres de los socios del emprendimiento; nombres de santos, dioses, montañas, reminiscencias indígenas y vientos. Todo ello no resultó naif ya que el público demandaba cierta marca comercial por sobre otra o buscaba un departamento porque le gustaba el mote del edificio. ${ }^{11} \mathrm{~A}$ cada uno se le fue adjudicando una representación particular que hizo que se eligiera solo uno y se descartaran otros, incentivando el consumo.

\section{Las llamadas «unidades de temporada»: la tipología más exitosa}

Mar del Plata era reconocida como el destino estival más famoso y anhelado. Las inmobiliarias y las constructoras buscaban satisfacer las necesidades de un amplio espectro de compradores no residentes por lo que la oferta se encasillaba en unidades de temporada de uno y dos ambientes (o ambiente y medio).12 Este fue el nicho de mercado más dinámico, codiciado y rentable por la cantidad de unidades que se podía sacar por edificio. Los espacios estaban pensados para permanecer poco tiempo dentro de estos, de modo de cubrir las necesidades básicas de habitación.

El uso veraniego estaba atravesado por sentimientos idílicos tan contrarios a su verdadera naturaleza, en tanto, en la mayoría de los casos las escasas condiciones de habitabilidad eran patentes. Algunos totalmente agazapados, en contrafrente o al interior (carentes de luz natural y ventilación), levantados en una de las arterias

${ }_{11}$ W. Jatton (ex integrante de la firma inmobiliaria Jatton- Martin), entrevista personal, agosto de 2018. 12 «Donde la construcción sigue al turismo», El Economista [Buenos Aires], nov. 14, 1969, p. 8. 
principales de la ciudad. Cabe destacar, que la consigna «frente al mar» podía atribuirse a solo a una parte selecta de los edificios y dentro de estos a los departamentos que daban a la calle, que también constituían un ínfimo porcentaje.

Muchas empresas se adhirieron a ciertos criterios de construcción de la época, hoy en día vistos como deficientes. Así, se aprovechaba por frente y fondo todo el terreno, prácticamente carecían de cocheras y presentaban ciertas características como la inexistencia de dependencias de servicio, placares chicos, baños muy pequeños, cocinas reducidas y poca iluminación. Las habitaciones que se proyectaban para cada departamento tendieron a reducirse en número y en amplitud. Sobre fines de la década del sesenta y en la siguiente, se comenzaron a construir más departamentos por piso (reduciendo los espacios) y por edificio, de modo de explotar al máximo el factor de ocupación posible.

La tipología que acabamos de reseñar se convirtió en el estándar de la costa reproducida también en los balnearios al sur de Mar del Palta como Necochea y Miramar. La existencia de un pequeño baño y una kitchenette (cocina reducida) contiguamente al dormitorio permitían que su precio fuera más accesible y vendible. El epítome de esta conceptualización en el plano de la proyección fue la arquitecta Débora di Veroli (2006 33), quien trabajó para una de las empresas más grandes y paradigmáticas del período, al ofrecer en masa este tipo de unidades de temporada en sus edificios propios denominados Eiffel. ${ }^{13}$

Di Veroli se convirtió en maestra del cálculo, aprovechamiento y explotación de las medidas mínimas que concedía el reglamento de construcciones vigente. Por ejemplo, logró reducir la superficie del baño (1,50 m x 2,20 m) inaugurando el llamado multifaz donde se instalaba el inodoro, un lavatorio y en ángulo un conducto de ventilación (34). Junto con la kitchenette, el calefón en el baño, los balcones reducidos y la pileta de lavadero (que daba al pulmón del edificio), se lograba reducir al mínimo la independencia de ambientes maximizando el uso de materiales, el costo del $\mathrm{m}^{2}$, las superficies cubiertas, la distribución en cada planta y las ganancias inmobiliarias. La circulación en cada piso se daba a través de largos pasillos con múltiples viviendas de reducidas dimensiones a ambos lados. Este modelo tuvo gran éxito ya que, además de

${ }_{13}$ Mónica Fiorentini (sobrina de Domingo), entrevista personal, abril de 2019. 
venderse rápidamente, fue imitado por otras empresas y varios arquitectos del rubro en el microcentro.

La búsqueda de la rentabilidad del suelo por parte de los actores económicos tuvo como consecuencia la producción de un corredor especulativo a ambos márgenes, y en las inmediaciones, de la avenida Colón, una de las arterias más importantes y perpendicular al mar. Sin embargo, la urbanización de esta línea fue dispareja dada la construcción de edificios en diferentes estilos durante más de tres décadas. En esta zona los departamentos dentro de un edificio entre medianeras y esquina se reservaban con función estival y ajustados a la necesidad del veraneante. Al transformarse en una «segunda vivienda» de uso temporario su calidad no se encontraba sistematizada, aunque sí parecía estar estandarizada con patrones mínimos de habitabilidad y el aprovechamiento o explotación de las medidas reglamentarias.

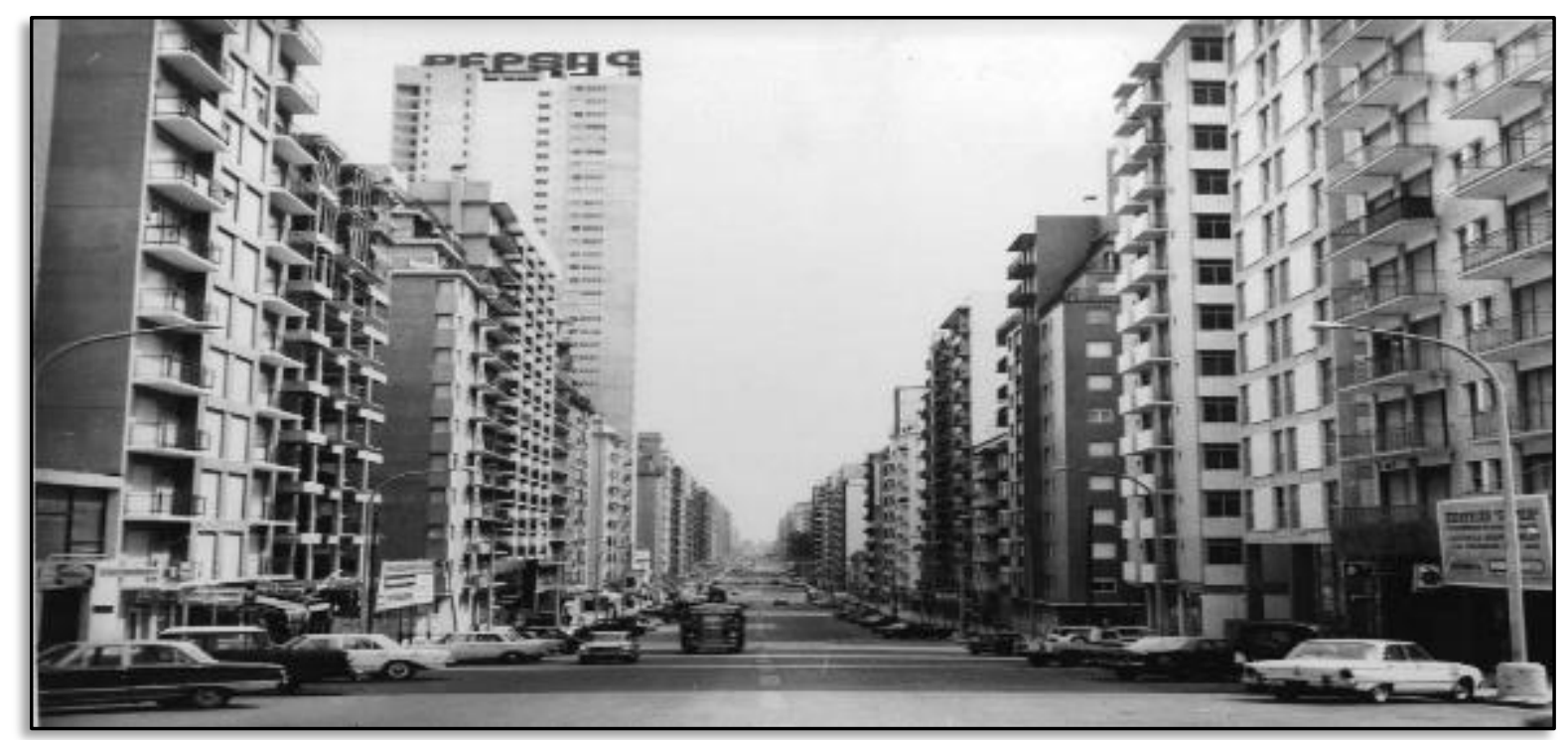

Unidades de temporada en la Av. Colón, año 1969. (Fuente: Fototeca Archivo Museo Histórico Municipal Roberto Barili)

Más tarde, tales objetos de consumo, que aparecieron en grandes cantidades, fueron caracterizados como verdaderas «pajareras» o «colmenas de cemento» por la opinión pública y hasta por los mismos usuarios. Cabe destacar, sin embargo, que existían determinadas empresas que se diferenciaban de sus competidores mayoritarios ofreciendo viviendas de buenos materiales, mejor iluminación y un confort particular.

Aquí lo que llama la atención es que el presunto destino de veraneo y vacaciones estuvo acompañado de una oferta de alojamiento con una densidad y amontonamiento 
de turistas muy importante. Los estilos arquitectónicos del medio siguieron los patrones del modernismo: los rascacielos. El conjunto edilicio creado se asimilaba más a una gran ciudad que a un balneario de descanso. De hecho, durante la temporada la gran actividad urbana en el centro trajo aparejados problemas inexistentes durante el invierno. Por ejemplo, recién en junio de 1969 se sancionó un decreto municipal obligando la construcción de cocheras en edificios ya que el congestionamiento automotor era el gran problema de cada temporada. ${ }^{14}$

\section{El origen de los compradores}

La construcción para la gente de Mar del Plata no camina, aquí todos los sueldos son bajos. Se vende a la gente de afuera, especialmente a aquellos que ya tienen sus casas en Buenos Aires y desean adquirir mayor status comprándose un coche $y$ un departamento en Mar del Plata (La Capital, [Mar del Plata], may. 25, 1969:16)

En la época, los posibles adquirentes de unidades de departamentos recorrían un abanico variopinto de posibilidades y de funcionalidades para las inmobiliarias. En principio, los veraneantes provenientes de cualquier lugar del país, quienes buscaban satisfacer las necesidades de alojamiento en temporada. Junto a ellos se ubicaban los interesados que tenían la idea de retirarse o jubilarse en un futuro en la costa; en segundo lugar, los ciudadanos locales que lograban acceder a una primera vivienda o aquellos que preferían vivir en el centro y cerca del mar aprovechando los servicios comerciales. En tercer lugar, con la ampliación de la oferta educativa y la apertura de la universidad en 1962 (nacionalizada en 1975), el mercado se amplió hacia clientes de los alrededores o de otras localidades bonaerenses. Estos buscaban comprar una vivienda para sus hijos que iban a estudiar durante el año a Mar del Plata. ${ }^{15}$

Ahora bien, el nicho de mercado más rentable y más explotado fue el primero, mientras que los restantes se ubicaron ampliamente por detrás. En este sentido, la evidencia empírica nos muestra que los primeros en acceder de forma mayoritaria a un departamento fueron inversionistas de Buenos Aires que, a su vez los revendían con

\footnotetext{
${ }_{14}$ A la vez, la reglamentación puesta en práctica premiaba al que lo hacía, ya que se permitía superar el límite de los factores de ocupación del edificio proyectado. La Capital [Mar del Plata], jun. 27, 1969:16. 15 Entrevistas a los principales agentes inmobiliarios del período: Héctor Barrera (socio fundador de la inmobiliaria Nannini-Barrera), entrevista personal, enero de 2017; Santiago Cocetta (histórico martillero público-tasador), entrevista personal, febrero de 2017; W. Jatton (agente inmobiliario local, integrante de la firma Jatton-Martin), entrevista personal, febrero de 2017.
} 
grandes ganancias. A grandes líneas, entre los clientes se puede observar la presencia de personal categorizado o gente de medianos recursos como maestras, pequeños comerciantes, trabajadores especializados, bancarios y otros, ya que con un ahorro se pagaba el anticipo y las primeras cuotas. ${ }^{16}$

Desde fines de los cincuenta existieron determinadas organizaciones inmobiliarias que vendían a precios económicos y otorgaban créditos para tales fines a empleados municipales, bancarios, casineros, a las Fuerzas Armadas, el Correo, el Ferrocarril, la Policía Federal, el Ministerio de Educación y Justicia y a otras reparticiones oficiales. En este plano, se financiaron horizontales o se compraron edificios enteros o unidades de departamentos con ciertas facilidades de las que el público corriente no disponía.

Según notifican los empresarios constructores de la época, en el nicho de mercado más popular se estilaba que se unieran dos o tres miembros de una misma familia para poder hacer frente a los pagos. Mientras que la ocupación de las unidades durante el verano se hacía de manera compartida o alternada. En síntesis, el medio local no contaba con un poder de compra suficiente y mayoritario capaz de absorber la gran oferta de departamentos. Si bien se pueden encontrar dueños de origen marplatense, estos fueron minoritarios frente a los «consumidores temporarios» provenientes de otros lugares geográficos. Entonces, podemos afirmar que se construía una ciudad para «otra ciudad» la cual se subsumía bajo la lógica del mercado turístico. ${ }^{17}$

Así, uno de los principales agentes inmobiliarios de la localidad apuntaba, ante la pregunta de «¿Quiénes compran en Mar del Plata?», lo siguiente:

Haciendo una clasificación por provincias es válido sostener que las mayores operaciones de venta no provienen de adquirentes radicados en el interior del país. El promedio que

\footnotetext{
16 Fuente: Lista de compradores de edificios en propiedad horizontal de diferentes empresas e inmobiliarias de la ciudad.

${ }_{17}$ Desde la década del sesenta se comenzó a percibir la gran cantidad de departamentos desocupados y «edificios vacíos» durante el resto del año. En 1974 se llevó a cabo el I Congreso Mundial de Inquilinos en una ciudad con cuarenta mil viviendas desocupadas (departamentos, mansiones y chalets de veraneo) que, según estimaban, podían albergar a doscientas mil personas. Un año después la Unión del Comercio, la Industria y la Producción (UCIP) aducía que fuera de la temporada estival permanecían desocupadas 75.00o unidades habitacionales. La Capital [Mar del Plata], nov. 17, 1980, p. 17.
} 
nosotros tenemos adjudica un $15 \%$ de las compras al interior contra el $85 \%$ provenientes de la provincia de Buenos Aires y Capital Federal ${ }^{18}$

$\mathrm{Si}$ analizamos las listas de compradores de departamentos registradas por las empresas constructoras para cada edificio tenemos un panorama más profundo. Las nóminas de adquirentes de unidades (habitables) resultan una fuente privilegiada al consignar los nombres (en algunos casos también la «ocupación»), la localidad de origen y el domicilio de los clientes, junto con las fechas de compra/posesión, y los planes de pagos elegidos. Una muestra de dos edificios en los momentos de mayor dinamismo del mercado inmobiliario local arroja los siguientes datos:

\section{Ejemplo n. ${ }^{\circ} 1$}

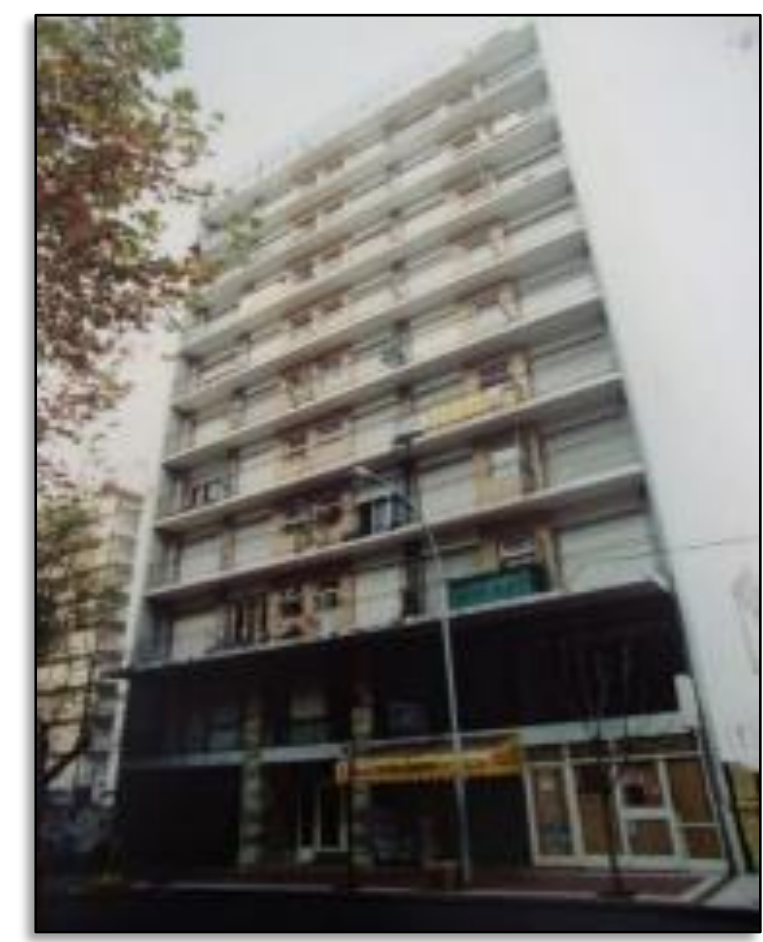

-Detalle de compradores/ propietarios

Total de unidades: 107

-Ciudad de origen: Capital Federal: 42

Provincia de Buenos Aires: 34

Mar del Plata: 28

Otros: Rosario: 1, Río Gallegos: 1, Santa Cruz: 1

\begin{tabular}{|l|l|l|l|l|}
\hline \multicolumn{1}{|c|}{ Edificio } & $\begin{array}{c}\text { Año de } \\
\text { construcción }\end{array}$ & ${\text { Cantidad de } \mathbf{~ m}^{2}}^{\mathbf{2}}$ & \multicolumn{1}{|c|}{ Ubicación } & Empresa constructora \\
\hline Gulfi VII & 1968 & $5.870 \mathrm{~m}^{2}$ & Macrocentro & Pulichino Hnos. y Cía. SCA \\
\hline
\end{tabular}

Fuente: Nómina de compradores Edificio Gulfi viI. Archivo privado Pulichino Hnos. y Cía. SCA, Mar del Plata, Argentina

${ }^{18}$ El Economista [Buenos Aires], nov. 14, 1969, p. 9. 


\section{Ejemplo n. ${ }^{\circ} 2$}

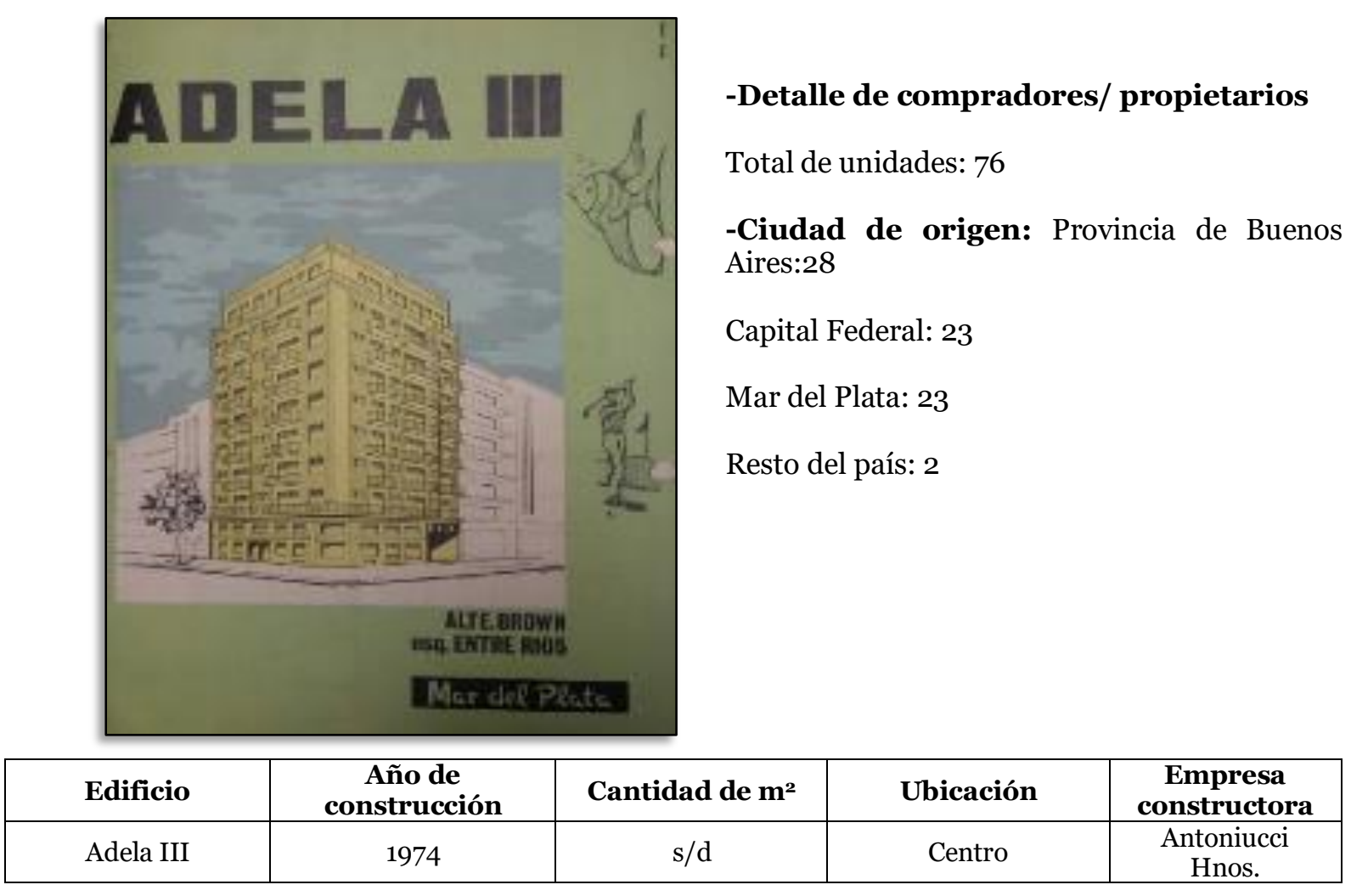

Fuente: Departamento de Catastro y mensuras. Nomenclatura catastral, Inmueble Brown 2151. Municipalidad de Gral. Pueyrredón, Mar del Plata, Argentina

El primer caso nos muestra la preponderancia de Capital Federal como ciudad de origen de los compradores, mientras que en segundo lugar se ubican algunas localidades de la provincia de Buenos Aires. En última instancia, aparecen los dueños locales. No obstante, dentro de este grupo contabilizamos los denominados departamentos de gremios (forma de pago a los «anexos» intervinientes) y aquellos que quedaron en poder de la propia firma propietaria o a nombre de algún familiar con el fin de ponerlos en alquiler.

En el segundo caso se entrevé un panorama similar al contar con la presencia mayoritaria del Gran Buenos Aires y la provincia homónima. Entre las localidades y los partidos que aparecen son: Lomas de Zamora, Moreno, Lanús, Avellaneda, Olivos, Florencio Varela, León Suárez, Wilde, Magdalena, Castelar, Banfield, Remedios de Escalada, Hurlingham, Florida, Quilmes, Haedo, Lobos y La Plata. Seguidamente, Capital Federal vuelve a aparecer en un rango preponderante mientras que los compradores locales suman un total de 23 (9 de los cuales pertenecen a la familia propietaria y a los socios del emprendimiento). 
Ante la escasez de estadísticas oficiales, ambos ejemplos vislumbran una tendencia generalizada para el período estudiado y en toda la oferta de edificios de la ciudad en diferentes empresas e inmobiliarias. Las decenas de listas de compradores que hemos podido recuperar de diversas firmas discriminan la categoría ocupación, pero lamentablemente no fueron completadas con el rigor que nos hubiera permitido realizar un análisis comparativo. Sí está claro que son las llamadas profesiones liberales las que aparecen reiteradamente: abogado, médico o contador o trabajador independiente. Sin embargo, el «domicilio» puede ser un indicador del nivel social al igual que el tiempo que tardó cada cliente en tomar «posesión» de la unidad (siempre en los meses de verano) tras comenzar la compra. Ello solía demandar de uno a cuatro años dependiendo de los refuerzos de cuotas y la cancelación del total.

Los principales clientes y consumidores del «turismo de cemento» provenían de la capital del país y su zona de influencia. Por ende, buscaban departamentos que se amoldaran a sus necesidades y a sus gustos. Lógicamente, en los alrededores de la Playa Bristol y el Casino se ubicaba la mayor oferta de servicios y de distracciones, pero se conseguían las unidades más reducidas y el mayor nivel de congestión. El precio se mantenía más alto alrededor de los espacios verdes un poco alejados del microcentro, como la Plaza Mitre y la Playa Grande, donde se podían encontrar ambientes de mayor categoría. A lo largo de la calle Colón los precios iban variando de acuerdo a las cercanías con la plaza del mismo nombre (y, por ende, del mar), pudiendo costar tres veces más. ${ }^{19}$ Por último, un segmento más popular se ubicaba en el barrio de la Terminal de ómnibus y hacia la zona oeste comprendiendo también a los monoambientes del centro.

\section{Conclusión}

El presente trabajo analizó una de las patas del fenómeno turístico más importante de la Argentina en las décadas centrales del siglo Xx. En esta época el horizonte de expectativas y las perspectivas culturales de los sectores medios se ampliaron. Como consecuencia, nacieron otras oportunidades de consolidar una movilidad social ascendente y una mejor posición económica. Como aducen varios autores, el peronismo fue esencial desde el discurso, pero también desde la práctica

19 «Los precios de los departamentos a estrenar en el radio céntrico», El Trabajo [Mar del Plata], dic. 19, 1967, p. 14. 
para consolidar una identidad determinada. Por otro lado, las particulares condiciones estructurales de la economía argentina entre 1950 y 1970 moldearon las posibilidades de ahorro y consumo de la sociedad.

Dentro del conjunto de representaciones ligadas al status social justamente el ocio tuvo un rol importante a la hora de marcar ciertas pautas de comportamiento, aspiraciones de larga data y un estilo de vida determinado. Mar del Plata fue el sitio donde se materializaron las nuevas perspectivas: la compra y el uso temporal de departamentos de veraneo se configuró como un patrón de consumo de las clases medias argentinas. Hemos explicado que las causas de este fenómeno se pueden encontrar en el largo, en el mediano y en el corto plazo. En principio, desde finales del siglo XIX la localidad se constituyó como el balneario más importante de la Argentina y en uno de los lugares de consagración social. A lo largo de varias décadas tener una propiedad en la costa fue una prerrogativa de los sectores más adinerados del país. Esta fue una aspiración social a perdurar con un gran poder simbólico y un carácter performativo.

En lo coyuntural, en los años cuarenta y cincuenta la inversión en propiedades se transformó en una de las vías inmejorables de canalización de ahorros, de reserva de valor y de protección de capital frente al deterioro de otras opciones, como aduce el economista Eduardo Corso. Por último, la puesta en práctica de la Ley de Propiedad Horizontal en 1948 materializó la ampliación de posibilidades de acceso a una vivienda bajo condiciones óptimas. Empíricamente, la división de la propiedad hizo posible la amortización de los costos de construcción posibilitando la compra de unidades más pequeñas a un precio asequible.

La conjunción de estas variables generó una época de explosión inmobiliaria y de gran crecimiento urbano de Mar del Plata. Los nuevos edificios de departamentos se construyeron a lo largo del litoral marítimo de modo de aprovechar sus atractivos naturales. Rápidamente, estos inmuebles se colocaron en el mercado de viviendas temporales y se dirigieron a una demanda externa al medio. Justamente, los nuevos productos podían solucionar el problema de alojamiento de cada temporada para los visitantes. Los mejores ubicados dentro de la escala social para aprovechar estas ventajas y administrar el tiempo libre fueron las clases medias urbanas. 
Como vimos, el uso de la publicidad por parte de los promotores e intermediarios inmobiliarios se convirtió en una de las herramientas principales de captación de clientes. La gráfica utilizada en la prensa, junto con las leyendas de venta en cada folleto, buscó reproducir la figura del veraneante propietario. Esta idea no era nueva, lo novedoso fue la conquista de esa posibilidad por parte de amplios sectores sociales de estrato medio y la velocidad de consumo de un tipo de bien moderno. A través de dos de las firmas más resonantes del momento (Maral y Nannini-Barrera), pudimos entrever que las imágenes se dirigieron a un público distinguido con aspiraciones sociales de ascenso y de consolidación económica. De este modo, los departamentos en altura se transformaron en objetos deseados y necesarios para mantener y ostentar un determinado estilo de vida.

Por otro lado, los estímulos sensoriales y los valores asociados a las vacaciones fueron claves. En síntesis, la promesa del disfrute del mar, sumado a buenos planes de financiación, fue un atractivo singular. Las marcas comerciales creadas por las empresas locales lograron un reconocimiento dentro del mercado y una identificación con determinadas características de las obras. En paralelo, los nombres de fantasía con que se bautizaron los edificios fueron un acicate para garantizar el consumo.

La oferta se especializó en un tipo arquitectónico muy exitoso que fue conocido en la época como «unidades de temporada». Sus características morfológicas y estéticas, junto con la funcionalidad interna, estuvieron estrictamente asignadas a una utilidad transitoria. Si bien hubo diferentes segmentos de mercado, la mayoría adoleció de buenas condiciones de habitabilidad con la existencia de espacios reducidos o contiguos (cocina, baño y habitación) y la ausencia de otros (dependencias de servicio, cocheras, lavadero). Indudablemente, las empresas constructoras y los profesionales de obra tuvieron un rol central en la creación y adecuación de los edificios a estas necesidades. En este sentido, lograron maximizar el uso de materiales, las superficies cubiertas, la distribución en cada planta y las ganancias por las ventas, paralelamente a la reducción de los costos por $\mathrm{m}^{2} \mathrm{y}$ de los tiempos de construcción. Los ejemplos más acabados de este paradigma fueron los edificios emplazados a lo largo de la avenida Colón y los proyectos de la arquitecta Di Veroli. Evidentemente, como el objetivo era usar la vivienda por un tiempo determinado y desocuparla durante el resto del año, cumplía solo una necesidad transitoria. De modo que las pretensiones (y la capacidad de compra) de los interesados no eran las mismas que para una de tipo permanente. 
Finalmente, hemos establecido que el principal consumidor de estos bienes era oriundo de Buenos Aires y de sus alrededores. Así lo demuestran las listas de compradores de las inmobiliarias y de las empresas de la época. Mar del Plata resultó ser uno de los destinos más cercanos para elegir pasar las vacaciones. El cliente se fue estandarizando al igual que la publicidad para captarlo. Por otra parte, la población local no contaba con los recursos económicos ni con la capacidad de ahorro que tenían los sectores prósperos provenientes de la capital del país. Lo que hemos denominado «turismo de cemento» fue un rasgo identitario y un afán de consumo de las clases medias argentinas entre 1950 y 1970.

\section{Obras citadas}

\section{Fuentes}

Archivo Arq. Raúl Camusso, Colegio de Arquitectos de la Provincia de Buenos Aires, Distrito IX.

Archivo de empresas e inmobiliarias, Mar del Plata, Argentina: Pulichino Hnos. y Cía. SCA, Scheggia Hnos. SA, Nicolás Dazeo SA, Domingo Fiorentini SA, NanniniBarrera, Cía. Marplatense de Construcciones SA, Fiorentini Constructora SA.

Archivo de la Imagen y la Palabra, CeHis, Mar del Plata, Argentina.

Clarín [Buenos Aires, 1987]

Entrevistas personales (realizadas por el autor): Santiago Cocetta (histórico martillero público-tasador), febrero de 2017; Alberto Shalom (fundador y propietario de Edificadora Maral), agosto de 2016; Mónica Fiorentini (sobrina de Domingo), abril de 2019; Héctor Barrera (socio fundador de la inmobiliaria NanniniBarrera), enero de 2017; W. Jatton (agente inmobiliario local, integrante de la firma Jatton-Martin), febrero de 2017 y agosto de 2018

El Economista [Buenos Aires, 1969]

El Hogar (1950-1960)

El Trabajo [Mar del Plata, 1960-1970]

La Capital [Mar del Plata, 1950-1982]

La Nación [Buenos Aires, 1950-1970]

\section{Bibliografia}

Aboy, Rosa, «Ciudad, espacio doméstico y prácticas de habitar en Buenos Aires en la década de 1950. Una mirada a los departamentos para las clases medias», Nuevo Mundo Mundos Nuevos, 2010. Disponible en: https://journals.openedition.org/nuevomundo/59215

- - - - «Mafalda en casa. Departamentos de clase media y vida cotidiana en los años sesenta», Anales del Instituto de Arte Americano e Investigaciones Estéticas 
Mario J. Buschiazzo, Vol. 41, 2011, pp. 179-188. Disponible en: https://publicacionesfadu.rec.uba.ar/index.php/anales/article/view/40.

- «Departamentos para las clases medias: organizaciones espaciales y prácticas de domesticidad en Buenos Aires, 1930 ", Estudios Interdisciplinarios de América Latina y El Caribe. Vol. 25, 2014, pp. 31-58. Disponible en: http://eial.tau.ac.il/index.php/eial/article/view/1138.

Adamovsky, Ezequiel, Historia de la clase media argentina. Apogeo y decadencia de una ilusión, 1919-2003, Buenos Aires, Booket, 2015.

Ballent, Anahí, «Casa colectiva, monobloque, propiedad horizontal. Desplazamientos y Cruces de modelos en la habitación colectiva», en: Liernur, F. y Ballent, A., La casa y la multitud. Vivienda, política y cultura en la Argentina moderna, Buenos Aires, Fondo de Cultura Económica, 2014, pp. 461-487.

Bartolucci, Mónica (ed.), Mar del Plata. Imágenes urbanas, vida cotidiana y sociedad, Mar del Plata, UNMDP, 2002.

Corso, Eduardo, «Un repaso por la historia de las opciones de ahorro del sector privado argentino», Colectivo Económico, abr. 4, 2014a. Web. Disponible en: https://colectivoeconomico.wordpress.com/2014/04/04/un-repaso-por-lahistoria-de-las-opciones-de-ahorro-del-sector-privado-argentino/.

-- - - «Mar del Plata, nuestro «shadow banking» junto al mar», Alquimias Económicas, sep. 30, 2014b. Web. Disponible en: https://alquimiaseconomicas.com/2014/09/30/mar-del-plata-nuestroshadow-banking-junto-al-mar/.

Di Veroli, Débora. Di Veroli, Débora, arquitecta: vida, obra y reflexiones, Buenos Aires, ed. de la autora, 2006.

Gerchunoff, Pablo y Lucas Llach. El ciclo de la ilusión y el desencanto. Un siglo de políticas económicas argentinas. Buenos Aires, Ariel Sociedad Económica, 1998.

Lanciotti, Norma; Abraham Lavih; Florencia Brizuela y Marco Kofman. «Notas sobre el mercado inmobiliario en Rosario, 1916-1966», X Jornadas de Economía Crítica, Universidad Nacional de General Sarmiento, Los Polvorines, Buenos Aires, 2017

Lluch, Andrea (ed.), Las manos visibles del mercado. Intermediarios y consumidores en la Argentina, Rosario-La Pampa, Prohistoria, 2015.

Oliven, Rubén George, «Clase media, consumo y ciudadanía», en Adamovsky, E. Visacovsky, S. y Vargas, P (Comps.), Clases medias: nuevos enfoques desde la sociología, la historia y la antropología, Buenos Aires, Ariel, 2014, pp. 201-212.

Pastoriza, Elisa (ed.), Las puertas al Mar. Consumo, ocio y política en Mar del Plata, Montevideo y Viña del Mar, Buenos Aires, Biblos, 2002.

--_- La conquista de las vacaciones. Breve historia del turismo en la Argentina, Buenos Aires, Edhasa, 2011.

- y Juan Carlos Torre. Mar del Plata, un sueño de los argentinos, Buenos Aires, Edhasa, 2019. 
Pegoraro, Víctor, «Mar del Plata, el «mercado inmobiliario del ocio». La industria de la construcción entre 1930 y 1981», Anuario del CEED, Vol. 9, 2017, pp. 213-253. Disponible en: http://ojs.econ.uba.ar/index.php/CEEED/article/view/1032.

- - - - «Apuntes para una historia de la propiedad horizontal en Mar del Plata (1948-1982)», Pasado Abierto, Vol. 7, 2018, pp. 166-187.

Pérez, Inés, «Apuntes para el estudio del consumo en clave histórica», Avances del Cesor, Vol. 13, 2015, pp. 97-106. Disponible en: https://rephip.unr.edu.ar/bitstream/handle/2133/12904/Apuntes\%20para\%2 oel\%20estudio\%2odel\%20consumo\%20en\%20clave\%2ohist\%C3\%B3rica.pdf? sequence $=3$.

Rocchi, Fernando, «Consumir es un placer: La industria y la expansión de la demanda en Buenos Aires a la vuelta del siglo pasado», Desarrollo Económico, Vol. 148,

1998, pp. 533-558. Disponible en: https://www.jstor.org/stable/3467411?seq=1. — «La sociedad de consumo en tiempos difíciles: el modelo estadounidense y la modernización de la publicidad argentina frente a la crisis de 1930», Historia Crítica, Vol. 65, 2017, pp. 93-114. Disponible en: http://www.scielo.org.co/scielo.php?pid=So12116172017000300093\&script=sci_abstract\&tlng=en 